\title{
THE FUNCTIONS OF THE 1945 CONSTITUTIONAL PREAMBLE
}

\author{
Andy Omara* \\ Department of Constitutional Law, Faculty of Law, Universitas Gadjah Mada, Yogyakarta \\ Jalan Sosio Justisia 1 Bulaksumur, Sleman, DI Yogyakarta, 55281
}

\begin{abstract}
What are the functions of the Preamble? This paper aims to answer this important question using the Preamble of the Indonesian Constitution namely the 1945 Constitution an example. Utilizing doctrinal approach as the research method, this paper argues that the functions of the 1945 Constitutional Preamble vary from time to time. In the Old Order and the New Order governments, the Preamble enjoyed its highest status but it somehow lacked of legal binding. In recent years, particularly after the recent constitutional amendments, the status of the Preamble arguably shifted from lacked of legal binding to have legal binding status. This shift is primarily because of the recent constitutional amendments.
\end{abstract}

Keywords: functions, preamble, constitution.

\section{Intisari}

Apa fungsi sebuah Pembukaan UUD? Artikel ini bermaksud menjawab pertanyaan penting dengan menggunakan Pembukaan Undang-Undang Dasar 1945 sebagai contoh. Dengan pendekatan doktrinal, artikel ini berpendapat bahwa fungsi dari Pembukaan UUD 1945 berbeda dari waktu ke waktu. Pada masa Orde Lama dan Orde Baru, Pembukaan mendapatkan tempat tertinggi. Namun pada saat yang sama ia tidak sepenuhnya mempunyai kekuatan mengikat secara hukum. Sejak perubahan Undang-Undang Dasar 1945 pada tahun 1999-2002, status Pembukaan berubah dari yang sebelumnya tidak sepenuhnya mempunyai daya ikat menjadi mempunyai kekuatan mengikat secara hukum. Hal ini sebagai konsekuensi dari perubahan Undang-Undang Dasar.

Kata kunci: fungsi, pembukaan, konstitusi.

\section{Pokok Muatan}

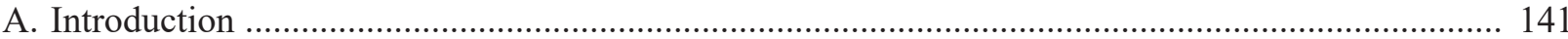

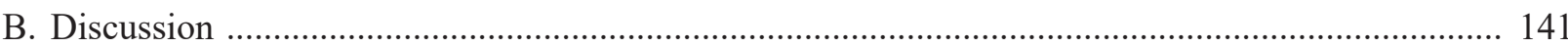

1. Some typologies on Constitutional Preamble ........................................................................... 141

2. The Origin of the Preamble of the 1945 Constitution: who drafted and how the Preamble

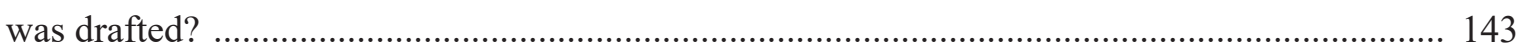

3. How are the characteristics of the Preamble of the 1945 Constitution? ..................................... 145

4. The Functions of the Preamble of the 1945 Constitution …........................................................ 151

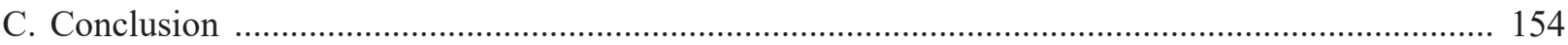




\section{A. Introduction}

Generally, a constitution consists of a preamble and the provisions or articles. ${ }^{1}$ But there are some constitutions that do not have a preamble, preface, or foreword. ${ }^{2}$ A preamble serves as an introduction to a constitution. Literature that focuses on constitutional preamble is arguably understudied. ${ }^{3}$ Most constitutional law literature focuses on the provisions or the body of the constitution and analyses how these constitutional provisions are implemented in practice. For this reason, this paper does not discuss the implementation of the constitutional provisions since it has been adequately discussed by many constitutional law scholars. Rather, it will discuss the preamble of a constitution.

This paper attempts to answer an important research question: What are the functions of a preamble? To answers this research question in a more concrete and specific in nature, this paper will use the Indonesian Constitution namely the 1945 Constitution as a case study. It argues that in the context of Indonesia, the functions of the Preamble of the 1945 Constitution is arguably changing from time to time. The Constitutional Preamble enjoyed its highest status during Old Order Soekarno and New Order Soeharto. At the same time, however, it lacked of legal binding force. The governments of the day arguably used the Constitutional Preamble as a political means to advance their political agenda. In the post-New Order era, however, there was a shift concerning the roles of the Preamble. The constitutional amendments in 1999-2002 to a certain extent changed the status of the Preamble from a supreme status into an integral part of the updated Constitution. The updated Constitution expressly determines that the Constitution consists of Preamble and Articles. This means both the Preamble and the body of the Constitution are inseparable elements of the new Constitution.

This paper proceeds as follows: Part $\mathbf{1}$ explains the concept of a preamble and presents some typologies concerning a constitutional preamble. Part 2 traces the origins of the Preamble of the 1945 Constitution, its legal status, and its roles from Old Order, New Order era, to the post-New Order government. Part 3 applies typologies explained in part 1 to the 1945 Constitutional Preamble and analyze where the Preamble of the Constitution is located under these typologies. This part also examines whether these typologies fit neatly with the 1945 Constitutional Preamble. Part 4 analyses the functions of the constitutional preamble of the old 1945 Constitution up to the updated 1945 Constitution (post constitutional amendment 19992002). This paper ends with a conclusion.

\section{B. Discussion}

\section{Some typologies on Constitutional Preamble}

Literature in constitutional law provides a different explanation on why a constitution has a preamble. Some literature explains that a preamble often constitutes the introduction to a constitution. ${ }^{4}$ It explains the history behind the enactment of a constitution, the nation's goals, or other important national principles. Others explain that a preamble express constitutional identity, social, and political norms. In short, it is safe to say that a preamble is collective values of a nation. For a constitution that does not have a formal preamble, the introductory article of the constitution often acts as a preamble.

\footnotetext{
Countries that have a preamble to their constitution include: Australia, Argentina, Brazil, Canada, France, Germany, India, Ireland, Indonesia, Japan, New Zealand, Portugal, the Philippines, Russia, South Africa, Turkey, and the United States. This list does not mention all countries in the world. There are many other countries that have a preamble to their constitution. This list of countries is solely to show that many countries' constitutions have a preamble.

These include the constitution of the following countries: Austria, Belgium, the Netherland, Denmark, Italy, Norway, Romania, Singapore and Sweden. Again, this is not an exhaustive list.

There are very few articles or book focusing on constitutional preamble. These include: Frosini, Justin Orlando. Constitutional Preambles. At a Crossroads Between Politics and Law. Vol. 70. Maggioli Editore, 2012. Law, David S. "Constitutional Archetypes.” Tex. L. Rev. 95 (2016) p. 153. Smith, Peter J., and Robert W. Tuttle. "God and State Preambles.” Marq. L. Rev. 100 (2016) p. 757. 
A preamble of a constitution can be classified into several different categories such as based on the language, content, or legal functions. Peter Haberle classifies constitutional preamble based on the language: 1) preamble with a solemn and celebrative language; 2) preamble that use very simple and everyday phrase, and 3) preamble that contain a highly technical and legalistic terminology. ${ }^{5}$ Other scholar such as David S. Law categories constitutional narratives of the preamble into: 1) liberal archetype, 2) statist archetype, and 3) a universalist archetype. ${ }^{6}$ Liberal archetype closely related to common law tradition which emphasize the imposition of limits upon government in the form of negative and procedural rights. $^{7}$ The statist archetype is associated with civil law tradition perceived the state as an embodiment of a distinctive community and the vehicle for the achievement of the community goals. ${ }^{8}$ It articulates the collective goals and positive rights that require an active role of the state and also the obligation of the citizens with the state to pursue the common goals. The universalist archetype, the legitimacy of the state to a certain extent relies on the normative force of global order. ${ }^{9}$ It includes the commitment to supranational institutions and supranational law.

Substantively, the preamble of a constitution can be classified into several different categories. Liav Orgad provides five categories regarding the content of a preamble. These five categories include the declaration of (1) the sovereign, (2) historical narratives, (3) supreme goals ${ }^{10}$, (4) national identity ${ }^{11}$, and (5) God or religion. ${ }^{12}$ These categories are slightly similar to Justin O. Frosini's classification which includes 1) the preamble as a gateway of entry for other sources of law; 2) the people are sovereign ${ }^{13} ; 3$ ) the form of state and the form of government; 4) historical references; 5) God and preamble; and 6) territorial identity. ${ }^{14}$ Tom Ginsburg, Nick Foti, and Daniel Rockmore add the content of the constitutional preamble as mentioned above with the following categories: specific religious figures, ${ }^{15}$ national historical events, ${ }^{16}$ or even a foreign policy ${ }^{17}$ statement. ${ }^{18}$

The final classification of constitutional preamble is based on its legal functions. A constitutional preamble can be classified into: 1) the ceremonial-symbolic, in which the preamble serves to consolidate national identity but lacks binding legal force; 2) the interpretive, in which the preamble is granted a guiding role in statutory and constitutional interpretation; and 3) the substantive, in which the preamble serves as an independent source for constitutional rights. ${ }^{19}$

It should be noted that a preamble perhaps contains elements more than one of these categories. it is often very difficult to make a distinction whether the content of a preamble refers to national

Frosini, Op.cit. p. 47

David S. Law “Constitutional Archetypes.” Tex. L. Rev. 95 (2016) p. 153.

Ibid. p. 166.

Ibid. p. 169

Ibid. p. 174

In addition, preamble often states the nation's goals such as the advancement of human rights, justice, or social welfare.

National identity such as a commitment to settle the dispute peacefully, or the words "liberty" or "human dignity" appears in the preamble of some countries constitutions.

12 Liav Orgad, The Preamble in constitutional interpretation, I.CON (2010). Vol. 8 No. 4, p. 716-718.

13 A preamble of a constitution often mentions the source of sovereignty. The Preamble of the U.S. Constitution, for example, mentions "we the people of the United State of America." https://www.usconstitution.net/const.html; The Preamble of the Spain Constitution states "the Spanish Nation." http://www.congreso.es/portal/page/portal/Congreso/Congreso/Hist_Normas/Norm/const_espa_texto_ingles_0.pdf

14 Justin O. Frosini, Constitutional Preambles at a Crossroads Between Politics and Law (2012); Ebrahim Afsah, Book Review, 11 Int'l J.Cons. L. p. 831-834 (2013) reviewing Frosini.

15 Some preambles mention: Jesus Christ (Ireland, Greece, and Fiji), Allah (Iran), Prophet Muhammad (Brunei). God or religion was explicitly mentioned in the preamble of the Ireland Constitution, the Canadian Charter, and the Swiss Constitution.

16 Historical Narratives was mentioned in the South Africa Constitution. The phrase "recognize the injustice of our past" shows the recognition of the sad history of the country. The South Africa Constitution http://www.justice.gov.za/legislation/constitution/SAConstitution-web-eng. pdf

17 For example: North Korea's Constitution, China Constitution, and Syria Constitution.

18 Tom Ginsburg, Nick Foti, and Daniel Rockmore, "We the Peoples": The Global Origins of Constitutional Preambles, 46 Geo. Wash. Int'l L. Rev. p. 305.

19 Liav Orgad, Op.cit. p. 722. 
identity, historical narratives, or territorial identity. These classifications are significant to understand the general characteristics of a preamble. However, it does not necessarily portray the whole picture of preambles in the real world.

2. The Origin of the Preamble of the $\mathbf{1 9 4 5}$ Constitution: who drafted and how the Preamble was drafted?

Since the Indonesian declaration of independence in 1945, Indonesia had four (or five) different constitutions i.e. the 1945 Constitution, the 1949 Federal Constitution, the 1950 Provisional Constitution, the 1945 Constitution post Presidential Decree July 5, 1959 and the 1945 Constitution (post1999-2002 amendments). All of these Constitutions have a preamble. The Preamble of the 1945 Constitution is the longest. It contains 182 words. The 1950 Constitution consists of 110 words, and the 1949 Federal Constitution is the shortest only 78 words. Comparatively, the number of words of Preamble of the Indonesian Constitutions is just above the average of word count of the constitutions in the world. ${ }^{20}$ The following part will trace the origin of the Preamble of the 1945 Constitution. It will answer an important question: Who drafted and how the Preamble of the 1945 Constitution was drafted?

The Preamble of the first constitution was written during the drafting of the 1945 Constitution. It was drafted just before the Japanese surrender and promulgated on August 18, 1945. ${ }^{21}$ Two committees worked on the document: 38 members of the Badan Penyelidik Usaha Persiapan Kemerdekaan Indonesia (Inventory Committee for the Preparation of the Indonesian Independence or BPUPKI) and
Chuo Sangi-In (an advisory body). ${ }^{22}$ The first session was held on May 29 up to June 1, 1945. The matters discussed in this session include the basis of state ideology (which included in the Preamble of the Constitution), the form of state and borders and other subjects. This draft was then further discussed by the nine Committee (Panitia Sembilan). ${ }^{23}$ The draft of the Preamble consists of four paragraphs. The contents of the preamble include, inter alia, the declaration of independence, the national goals, and most importantly the Pancasila -the state ideology. The draft of the preamble was mostly accepted by the BPUPKI as stated by Abdillah, "The discussion went smoothly expect for the part devoted to the foundation of state philosophy." ${ }^{24}$ only paragraph four of the Constitution which elaborate the state ideology -the Pancasila became the most contestable issue.

During the BPUPKI session, there were two political groups: one that in favor of Islamic state and the one that support separation between state and religion. ${ }^{25}$ The discussion about the foundation of state was far from easy. But the Panitia Sembilan finally reached a compromise in the form of the Jakarta Charter. ${ }^{26}$ The first principle of Pancasila says, 'Ketuhanan dengan kewajiban menjalankan syariat Islam bagi pemeluk-pemeluknya." or it can be loosely translated into Belief in God with the obligation for adherents of the faith to carry out Islamic sharia. These seven words of paragraph four of the preamble, "dengan kewajiban menjalankan syariat Islam bagi pemeluk-pemeluknya," could not be agreed among the constitutional drafters. ${ }^{27}$ These seven words commonly called Jakarta Charter (Piagam Jakarta). People of the eastern part

\footnotetext{
20 Id. The mean length of a preamble is 175 words. It is estimated that seventy five percent of all preamble contain fewer than three hundred words.

J.A.C Mackie, Indonesia Constitution 1945-60, in Richard Neville Spann, Constitutionalism in Asia (Asia Publishing House, 1963 ). p. 178. Bahar, Saafroedin, and Nanie Hudawatie. "Risalah Sidang BPUPKI dan PPKI." (1998). p. xxxiv-xxxv.

Id. The members of the nine committee are Soekarno, Mohammad Hatta, AA Maramis, Abikoesno Tjokrosoejoso, Abdoelkahar Moezakir, HA Salim, Achmad Soebardjo, Wachid Hasjim, and Muhammad Yamin.

24 Masykuri Abdillah, Actualization of Indonesian State Philosophy in the Context of Modern Democratic State in The Path to Alliance of Civilizations Through the Asian Community Alparslam Acikgenc, Choi Woo, Won, and Orhan Adiguzel (eds.) p. 124.

27 Moch Nur Ichwan, The Seven-Word Controversy, IIAS Newsletter March 2003, pp 23-24. http://old.iias.asia/iiasn/30/IIASNL30_23_Ichwan. pdf
} 
of Indonesia, who were mostly Christians, did not accept this clause. They would not join the unitary state of Indonesia if the constitution characterized it as an Islamic state. ${ }^{28}$ There was also diverse views among Muslim leaders, between those who believed that it is necessary to include the seven words and those who opposed state-enforced Islamic law. ${ }^{29}$ They also argued that it had been agreed that Indonesia was not based on a particular religion. ${ }^{30}$ The disagreement was bridged by the doctrine of Pancasila (five principles/precepts) laid down by Soekarno in June 1, 1945. The first principle of the Pancasila which initially consists of the seven words of the Jakarta Charter was finally deleted one day before the Constitution was introduced. The first principles of Pancasila said: Belief in one supreme God. By avoiding the name of a particular God, Indonesian identity is defined in religious but not in Muslim terms. ${ }^{31}$. On August 18, 1945, the 1945 Constitution which consists of Preamble and Articles was formally enacted. Since then the 1945 Constitution including its Preamble become the first Constitution of the Republic of Indonesia.

How is the legal status of the Preamble of this first Constitution? Two important factors -time of drafting and status of the framers of the constitution - determine the legal status of the Constitution. The first Constitution including its preamble was drafted during the revolutionary period when Indonesia struggled to gain independence. This constitutional drafting was in fact part of the Japanese colonial government promise to help Indonesia in preparing its independence. Knowing this circumstance, the founding fathers wanted to have a constitution as soon as possible so that Indonesia can declare its independence sooner. The intention of the founding fathers reflected on how quick the founding fathers drafted the Constitution. The constitutional drafting was less three months. Even though there are many different ideas come up during the constitutional drafting $^{32}$ the drafters focus on how to quickly complete the drafting of the Constitution. It is not surprising that the first constitution only consists of 37 articles. This quick process was acknowledged by Soekarno -the BPUPKI and PPKI member -who latter become the first President of Indonesia. Soekarno declares that this Constitution is a lighting constitution. ${ }^{33}$ Soekarno also acknowledged that it is not a perfect Constitution. ${ }^{34}$ The important thing, according to Soekarno, is the spirit of the government in running the country. ${ }^{35} \mathrm{He}$ also stated that this Constitution may be amended in the future when the situation and condition improved. ${ }^{36}$ Soekarno's statements mentioned above reflected the temporary status of the first Constitution including its preamble.

Concerning the role of the constitution and its preamble, it can be said that like any other constitutions, the first constitution serves as the highest law of the land which essentially mean that it become the reference of any laws and regulations. However, in October and November 1945 there were two decrees -the Government Maklumat and the Vice President Maklumat- which in essence change the constitution by changing the status of KNIP from assistant of president to legislative body and change the governmental system from presidential to parliamentary system. ${ }^{37}$ This two decrees showed

\footnotetext{
28 Bali, Asli U., and Hanna Lerner. "Constitutional Design Without Constitutional Moments: Lessons from Religiously Divided Societies." (2016). p. 261.

Ibid.

Bahar, Saafroedin, and Nanie Hudawatie. "Risalah Sidang BPUPKI dan PPKI." (1998). Xxxvi.

Bali, Asli U., and Hanna Lerner. Loc.cit.

Such as the intense discussion on whether it is necessary to include human rights and judicial review in the constitution.

Bahar, Saafroedin, and Nannie Hudawati. Risalah Sidang Badan Penyelidik Usaha-Usaha Persiapan Kemerdekaan Indonesia (BPUPKI), Panitia Persiapan Kemerdekaan Indonesia (PPKI), 28 Mei 1945-22 Agustus 1945. Sekretariat Negara Re, 1998. See also Saifudin, Lahirnya UUD 1945: Suatu Tinjauan Historis Penyusunan dan Penetapan UUD 1945" Unisia No. 49/XXVI/III/2003. p. $296,313$.

Ibid

The elucidation of the 1945 Constitution.

Ibid.

Maklumat Pemerintah 16 October 1945 and Maklumat Wakil Presiden November 1945.
} 
that while formally the constitution is the highest law of the land but in reality, it can be derogated by government and vice president decrees.

The 1945 Constitution was adopted until December 1949 Since then Indonesia adopted the 1949 Federal Constitution. This is because Indonesia shifted from a unitary state to a federal state. This change was one of the consequences of the Round Table Agreement between Indonesia and the Dutch which agree that Indonesia would be in the form of federation. The 1949 Constitution consists of a Preamble and articles. This Constitution however only lasted for about one year. The status of the 1949 Constitution is temporary because the framers of this constitution was not democratically elected. The significant role as this second constitution was not clearly seen because it only last about a year.

In 1950, Indonesia introduced a new constitution--the 1950 Provisional Constitution to replace the 1949 Federal Constitution. This new Constitution was initiated because most of the Indonesia regions wanted to return to a unitary state. This is based on the fact that Indonesia did not have a strong root of federalism. The 1950 Constitution consists of a Preamble and articles which largely similar to the preamble of the 1949 Federal Constitution. The change mostly on the form of state from federal to unitary state.

While this paper does not intend to analyze the Preamble of these two subsequence Constitutions, the brief explanation of the two Constitutions mentioned above is important to understand that Indonesia had two other constitutions other than the 1945 Constitution and both of them also had a preamble.

The 1945 Constitution was reintroduced in 1959 to replace the 1950 Constitution. The reinstatement of the 1945 Constitution because the constitutional drafters (the Konstituante) of the new constitution "failed" in carrying out its mandate to establish a new constitution. ${ }^{38}$ Considering that the 1950 Constitution is a provisional constitution and the failure of the drafters to establish a new constitution, the government decided to reinstate the 1945 Constitution. The new version of the 1945 Constitution consists of Preamble, Articles, and Elucidation. In its initial version of the 1945 Constitution, there was no elucidation.

The 1945 Constitution post 1959 which include a preamble, articles, and elucidation was valid and continue to operate during the New Order Government. The government of the day committed to consistently implemented the constitution. It did not intend to amend the Constitution. This is the reason why over four decades, there was no constitutional amendments. The 1945 Constitution stayed the same until the fall of the New Order Government in 1998.

\section{How are the characteristics of the Preamble of the 1945 Constitution?}

This section will analyze the features of the preamble of the 1945 Constitution. In doing so, it will use the categories of the content of the preamble provided by Liav Orgad and Tom Ginsburg. These include the declaration of: (1) the sovereign, (2) historical narratives, (3) supreme goals, (4) national identity, (5) God or religion, ${ }^{39}$ (6) religious figures, (7) national historical events, and (8) foreign policy. ${ }^{40}$ This section will also analyze the language of the Preamble using Peter Haberlee's and David S. Law's classifications.

Before discussing the content and the language of the Preamble, it is important to understand that the Preamble of the 1945 Constitution is relatively long compared to the Preamble of the 1949 Constitution and the Preamble of the 1950 Constitution. The fact that the preamble of the first constitution is the longest is an interesting feature. This is because the

\footnotetext{
38 Further discussion regarding the work of the constitutional drafters (the konstituante) in 1956-59 can be read in Nasution, Adnan Buyung. The aspiration for constitutional government in Indonesia: a socio-legal study of the Indonesian Konstituante, 1956-1959. Pustaka Sinar Harapan, 1992. This include a deep analysis regarding whether the konstituante failed to establish a new permanent constitution.

39 Liav Orgad, The Preamble in constitutional interpretation, Op.cit. p. 716-718.

40 Tom Ginsburg, Nick Foti, and Daniel Rockmore, "We the Peoples": The Global Origins of Constitutional Preambles, Op.cit. p. 305.
} 
formulation of the Preamble was not in a normal circumstance. It was written during the fight against the Dutch colonial government. How in such a situation the drafters of the Constitution were able to write such a long document?

There are three possible explanations. First, most, if not all, of the constitutional drafters have a high intellectual capacity. The majority of the BPUPKI and the PPKI members had been educated in Western Europe or had attended schools that were based on the Dutch educational system. ${ }^{41}$ The influence of western educational background of these committees was clearly seen when they drafted the constitution. ${ }^{42}$ They inserted some important constitutional principles which closely related to western ideas such as the distribution of powers, rule of law (rechtstaat), and limited government in the constitution. There is no strong indication that when drafting the preamble, the drafters look at a particular foreign country constitutional preamble. While there is no such indication, the educational background of the drafters to a certain extent influence the way they drafted the preamble as can be seen when they drafted the body of the Constitution. ${ }^{43}$

Second, the experience of colonialism over three centuries certainly influence the way the drafters of the constitution write the preamble. The painful experience in the past likely inspire the drafters in writing the preamble. It is not surprising that the first paragraph of the Preamble declares that independence is the right of all nations. The word independence or independent also come up in the subsequence paragraphs. The
Preamble also expressly mentions that colonialism against humanity and justice. The declaration of independence was also mentioned in the preamble. As mentioned in Indonesian Politic and Society, "The Preamble of the 1945 Constitution expresses the wishes and desires of Indonesian people to live in an independent, unified, sovereign, just and prosperous state. We are now free, unified and sovereign." ${ }^{44}$

Third, the drafters of the preamble also had relatively coherent views regarding the content of the preamble. In Abdillah words, "the discussion went smooth." ${ }^{45}$ expect the seven words that was finally deleted in the final version of the preamble. ${ }^{46}$ This situation certainly made things a lot easier and faster in drafting the preamble.

A combination between the intellectual capacity, the shared painful experience in the past, and the coherent views among the constitutional drafters certainly played significant roles in drafting the constitutional preamble.

How is the characteristics of the Preamble of the 1945 Constitution? The following part will examine the Preamble based on the content and the language. To gain a better understanding of how the Preamble looks like, below I present the Preamble in Bahasa Indonesia (Indonesian language) and English. At the far right of the table, I put some comments regarding the features of the Preamble. My comments are referring to Liav Orgad's and Tom Ginsburg's classification. The Preamble of the 1945 Constitution consists of four paragraphs. It reads as follows:

41 MPB. Manus, et al, Tokoh-tokoh Badan Penyelidik Usaha-Usaha Persiapan Kemerdekaan Indonesia I \& II "Leading Figures of Committee for the Preparation of the Indonesian Independence", (Departemen Pendidikan dan Kebudayaan Jakarta 1993). Such as Universiteit Leiden, Nederlandsch Handelshoogeschool, Rotterdam, Amsterdam, Berlin and Paris.

$42 \quad$ Ibid. p. 318-333

43 In formulating Pancasila, especially on the idea of Nationalism, Soekarno was inspired by Adolf Baars, a Dutch socialist thinker; Dr. Sun Yat Sen, the founder of the Republic of China; and Mahatma Gandhi. Faisal Ismail, Islam, Politic and Ideology in Indonesia: A study of the Process of Muslim Acceptance of the Pancasila (Dissertation Mc Gill University Montreal 1995) p. 34

44 David Burchier and Vedi R. Hadiz, Indonesian Politics and Society: A Reader, Routledge 2003, P. 296.

45 Masykuri Abdillah. Loc.cit.

46 Faisal Ismail, Islam, Politic and Ideology in Indonesia: A study of the Process of Muslim Acceptance of the Pancasila (Dissertation Mc Gill University Montreal 1995) p. 50 
Table 1. Undang-Undang Dasar Negara Republik Indonesia Tahun 1945 Pembukaan

(Preambule)

\begin{tabular}{l} 
Pembukaan \\
\hline Bahwa sesungguhnya kemerdekaan itu \\
ialah hak segala bangsa dan oleh sebab \\
itu, maka penjajahan di atas dunia harus \\
dihapuskan, karena tidak sesuai dengan \\
perikemanusiaan dan perikeadilan.
\end{tabular}

Dan perjuangan pergerakan kemerdekaan Indonesia telah sampailah kepada saat yang berbahagia dengan selamat sentausa mengantarkan rakyat Indonesia ke depan pintu gerbang kemerdekaan Negara Indonesia yang merdeka, bersatu, berdaulat, adil dan makmur.

Preamble
Whereas independence is the
inalienable right of all nations, of independence; against
therefore, all colonialism must be colonialism; respecting
abolished in this world as it is not in humanity and justice.
conformity with humanity and justice;

And the moment of rejoicing has arrived in the struggle of the Indonesian independence movement to guide the people safely and well to the gate of the independence of the state of Indonesia which shall be independent, united, sovereign, just and prosperous.

This paragraph acknowledges the national historical event from colonial government era to the Indonesian independence. It also illustrates the national goals of Indonesia: independent, united, sovereign, just and prosperous

\begin{abstract}
Atas berkat rakhmat Allah Yang Maha Kuasa dan dengan didorongkan oleh keinginan luhur, supaya berkehidupan kebangsaan yang bebas, maka rakyat Indonesia menyatakan dengan ini kemerdekaannya.
\end{abstract}

Kemudian dari pada itu untuk Subsequent thereto, to form a This paragraph shows the membentuk suatu Pemerintah Negara Indonesia yang melindungi segenap bangsa Indonesia dan seluruh tumpah darah Indonesia dan untuk memajukan kesejahteraan umum, mencerdaskan kehidupan bangsa dan ikut melaksanakan ketertiban dunia yang berdasarkan kemerdekaan, perdamaian abadi dan keadilan sosial, maka disusunlah Kemerdekaan Kebangsaan Indonesia itu dalam suatu Undang-Undang Dasar Negara Indonesia, yang terbentuk dalam suatu susunan Negara Republik Indonesia, yang berkedaulatan rakyat dengan berdasar kepada : Ketuhanan Yang Maha Esa, Kemanusiaan yang adil dan beradab, Persatuan Indonesia dan Kerakyatan yang dipimpin oleh hikmat kebijaksanaan dalam permusyawaratan/ perwakilan, serta dengan mewujudkan suatu Keadilan sosial bagi seluruh rakyat Indonesia. government of the state of Indonesia national goals (...to improve which shall protect all the people of public welfare, to educate Indonesia and all the independence the life of the people and and the land that has been struggled to participate toward the for, and to improve public welfare, to establishment of a world order educate the life of the people and to based on freedom, perpetual participate toward the establishment peace and social justice...); of a world order based on freedom, foreign policy (...to participate perpetual peace and social justice, toward the establishment therefore the independence of of a world order based on Indonesia shall be formulated into freedom, perpetual peace and a constitution of the Republic of social justice...); form of Indonesia which shall be built into government i.e. democratic a peoples sovereign state based on a government (peoples sovereign belief in the One and Only God, just state...)(and National and civilized humanity, the unity of ideology/identity (...a belief Indonesia, and democratic life led by in the One and Only God, wisdom of thoughts in deliberation just and civilized humanity, amongst representatives of the people, the unity of Indonesia, and and achieving social justice for all the democratic life led by wisdom people of Indonesia. of thoughts in deliberation amongst representatives of the people, and achieving social justice for all the people of Indonesia.) 
Table mentioned above shows the Preamble of the 1945 Constitution emphasize at least four important topics i.e. the right of independence, humanity and justice, the national goals, and national identity/ideology. The words independent or independence are mentioned at least seven times. The use of this word in the document is closely related to the situation when this Constitutional Preamble was drafted by the founding fathers. The long and hurting experience because of the occupation of the Dutch and the Japanese colonial government motivated the drafters to include these important and powerful word.

The inclusion of "humanity and justice" in the document also reflects the concern of the constitutional drafters regarding the consequences of colonialism. The Preamble then moves to the declaration of the ultimate goals that the country want to achieve. The phrase "independent, united, sovereign, just and prosperous" stated in paragraph two and the long sentence in paragraph four "shall protect all the people of Indonesia and all the independence and the land that has been struggled for, and to improve public welfare, to educate the life of the people and to participate toward the establishment of a world order based on freedom, perpetual peace and social justice," shows the direction of the country in the future.

The most unique and distinct character of the Preamble of the 1945 Constitution is the stipulation of the national ideology/identity namely Pancasila (the five precepts) in the final paragraph. Pancasila reads as follows:1) Belief in the One and Only God, 2) Just and civilized humanity, 3) The unity of Indonesia, 4) Democratic life led by wisdom of thoughts in deliberation amongst representatives of the people, and 5) Achieving social justice for all the people of Indonesia.

These five principles become one of the most important features of the Preamble. Pancasila is the state ideology that is accepted by all Indonesians regardless their backgrounds, entities, religions, and languages. Pancasila embraces all the Indonesian people with all their diversity. Pancasila is neither a secular ideology nor an ideology based on a particular religion.

The inclusion of Pancasila in the Preamble is a powerful tool to unify all Indonesians. The fact that Indonesia is diverse in many ways including the geographical location, culture, language, religions, and ethnicities, formulating an --all acceptedideology is challenging.

Even though Muslim is the majority, imposing Islamic teaching as a state ideology will not be accepted by eastern part of Indonesia which who are mostly Christians. Proposing a secular ideology will also likely be rejected as people of Indonesia are committed to their religious teachings. The features of the Preamble of the 1945 Constitution show how this Preamble is somewhat different from the features of preamble in general. The inclusion of state ideology in the preamble proves this indication.

In terms of the language, referring to Peter Haberlee's classification, the Preamble of the 1945 Constitution shows a combination between a solemn and celebrative language and uses simple and everyday phrase. But it did not contain a highly technical and legalistic terminology. ${ }^{47} \mathrm{~A}$ solemn and celebrative language can be seen in each paragraph of the Preamble. For example, the Preamble mention in very formal and official way about: the declaration of independence, the declaration against the colonialism, the acknowledgment of the right to independence, the declaration of the national goals and the declaration of national ideology. At the same time, however the language of the Preamble is somewhat simple. The content of the Preamble mostly self-explanatory. I think only a few terminologies and sentences that perhaps difficult to understand because they are vague and abstract. For example, in paragraph 4 especially regarding the national ideology (Pancasila). I would include the language of Pancasila perhaps in highly technical language ${ }^{48}$ Other than that, I believe the language 
of the preamble is quite straightforward.

In David S. Law classification, the language of the Preamble to some extent resembles the statist archetype. But certainly not liberal archetype or universal archetype. The Preamble of the 1945 Constitution does not have any reference to supranational institution or international law (universal archetype). It also does not expressly limit the government's powers (liberal archetype).

David S. Law typology suggests that the statist archetype is associated with civil law tradition. It perceived the state as an embodiment of a distinctive community. The state is the vehicle for the achievement of the community goals. ${ }^{49}$ In addition, it also articulates the collective goals and positive rights that require an active role of the state and also the obligation of the citizens with the state to pursue the common goals.

Similarly, the Preamble of the 1945 Constitution also contains some of the above elements. For example, Paragraph four mentions the collective goals of the nation as well as the positive rights that require an active role of the state. (...a government of the state of Indonesia which shall protect all the people of Indonesia and all the independence and the land that has been struggled for, and to improve public welfare, to educate the life of the people and to participate toward the establishment of a world order based on freedom, perpetual peace and social justice...). However, the Preamble does not mention the obligation of the citizens to pursue the national goals. It also does not expressly state that the state is an embodiment of a distinctive society. It is fair to say that while statist archetype can be used to explain the Preamble of the 1945 Constitution, it does not mean that the
Preamble of the 1945 Constitution fits neatly to this typology.

\section{a. Various views Regarding the Status of the Preamble}

There are at least two different view regarding the status of the 1945 Constitutional Preamble. The first view believes that the Preamble of the 1945 Constitution acts as guidance in the formulation of the provisions of the Constitution. The elucidation of the Constitution expressly mentions about the role of the Preamble. It stated that "UndangUndang Dasar menciptakan pokok-pokok pikiran yang terkandung dalam pembukaan dalam pasal-pasalnya." ${ }^{50}$ The Constitution creates points of thought contained in the preamble in its chapters. This means the preamble becomes the reference of the drafters in formulating the provisions of the constitution. In other words, the preamble has higher status than the body of the Constitution.

This tendency can also be explained by looking at the New Order government policy to maintain the originality of the 1945 Constitution. The New Order government also placed the Pancasila as source of law "the highest elements of the nation." 51 For example, the MPRS (the Provisional People's Consultative Assembly) issued a decree which stated that, ${ }^{52}$ the Preamble of the 1945 Constitution was one integral part of the proclamation of the independence. Therefore, it cannot be amended even by the People's Consultative Assembly who have the authority to amend the Constitution. This

\footnotetext{
Law, David S. “Constitutional Archetypes.” Tex. L. Rev. 95 (2016), p. 169.

Penjelasan UUD 1945 (the Elucidation of the 1945 Constitution).

Adrian Vickers, A History of Modern Indonesia, Cambridge University Press New York (2005) p. 161.

Tap MPRS XX/MPRS/1966 the original text says: "Pembukaan Undang-Undang Dasar 1945 sebagai pernyataan Kemerdekaan yang terperinci pengandung cita-cita luhur dari Proklamasi kemerdekaan 17 Agustus 1945 dan yang memuat Pancasila sebagai Dasar Negara, merupakan satu rangkaian dengan Proklamasi kemerdekaan 17 Agustus 1945 dan oleh karena itu tidak dapat dirubah oleh siapapun juga, termasuk MPR hasil pemilihan umum yang berdasarkan pasal 3 dan pasal 37 Undang-Undang Dasar berwenang menetapkan dan merubah Undan-Undang Dasar karena merubah isi pembukaan berarti pembubaran Negara. Dalam kedudukan yang demikian tadi Pembukaan Undang-Undang Dasar1945 merupakan dasar dan sumber hukum dari batang tubuhnya."
} 
is because changing the Preamble means dismissing the State. The Preamble of the Constitution is the foundation and the legal source of the constitutional articles.

Similarly, some constitutional law scholars $^{53}$ and the government ${ }^{54}$ placed the Preamble as the staatsfundamentalnorms. This means Pancasila was placed as the fundamental norms of the country. Because the Preamble is the fundamental norm, it could not be amended. They believe that changing the preamble of the 1945 Constitution means terminating Indonesia because the Preamble contains Pancasila - the state ideology- and the national goals. ${ }^{55}$

The second view believes that the Preamble is one integral part of the 1945 Constitution. This view is based on the Elucidation of the 1945 Constitution which state that, "pokok-pokok pikiran tersebut meliputi suasana kebatinan dari UndangUndang Dasar Negara Indonesia. Pokokpokok pikiran ini mewujudkan cita-cita hukum (rechtsidee) yang menguasai hukum dasar negara, baik hukum yang tertulis (undang-undang dasar) maupun hukum yang tidak tertulis. Undang-Undang dasar menciptakan pokok-pokok pikiran ini dalam pasalnya." This direct quote essentially means that the Preamble could be interpreted as a part of the 1945 Constitution. But it does not clearly indicate whether the Preamble and the provisions of the Constitution have an equal status.

This view can also be justified by looking at the history of the formulation of the Preamble. The Preamble of the 1945 Constitution was drafted simultaneously with the drafting of the provisions of the Constitution. While it is true that they are written at the same time and the Preamble is also one component of the Constitution, it does not clearly show that they have equal status.

In line with these constitutional provisions, Prof Ashiddiqie questions whether the Preamble of the 1945 Constitution is a staatsfundamentalnorm. He states that if the Preamble is a staatsfundametalnorm it should be an independent, separated document from the Constitution. This is because the preamble is the foundation to establish the Constitution. ${ }^{56}$ In fact, he further states, the Preamble of the Constitution is part of the 1945 Constitution as a whole. He further explains that when drafting the Constitution, the founding fathers also acknowledged that the community is still growing so there is no need to be in hurry to formulate the state fundamental norm. ${ }^{57}$ In addition, he also argues that when drafting the Constitution, the drafters discussed and deliberated the draft of the Preamble and the body of the Constitution simultaneously, which also indicates that both are equal in terms of their legal status. ${ }^{58}$ Last, he refers to article II additional provision which states that the 1945 constitution consists of the Preamble and Articles. ${ }^{59}$

While there are two different views

\footnotetext{
53 For example, Hamid Attamimi, Maria farida, and Notonagoro (Notonagoro coined the term: Pancasila as staatsfundamental norm) place Pancasila as state fundamental norm which have higher status than the body of the constitution and statutes. Indrati, Maria Farida, and Maria Farida. "Ilmu Perundang-Undangan: Jenis, Fungsi dan Materi Muatan.” Yogyakarta: Kanisius (2007). Attamimi, A. Hamid S. "Peranan keputusan presiden Republik Indonesia dalam penyelenggaraan pemerintahan negara: suatu studi analisis mengenai keputusan presiden yang berfungsi pengaturan dalam kurun waktu Pelita I-Pelita IV." (1990).

54 The new order government promised to, "defend Pancasila and UUD 1945 and purely and consistently implement them." (mempertahankan Pancasia dan UUD 1945 dan melaksanakannya secara murni dan konsekuen). Muchson AR, Pancasila dan UUD 1945 Dalam Kehidupan Bangsa dan negara Republik Indonesia Universitas Negeri Yogyakarta, 2009, p. 52.

Ibid. p. 6.

36 Jimly Asshiddiqie, Ideologi, Pancasila, dan Konstitusi “Ideology, Pancasila and Constitution” p. 7.

Ibid.

Ibid.

Ibid.
} 
regarding the Preamble of the 1945 Constitution, the majority believe that the Constitutional Preamble has higher status than the body of the Constitution. The influence of Hans Kelsen theory on the hierarchy of legislation seems significant. Pancasila which is mentioned in the Preamble serves as staatsfundamentalnorms (state fundamental norm) while the body of the Constitution acts as grundnorm (basic norm).

\section{The Functions of the Preamble of the $\mathbf{1 9 4 5}$ Constitution}

This section will analyze the Preamble of the 1945 Constitution based on its legal functions. In doing so, it will utilize Liav Orgad's constitutional preamble typology which include: 1) the ceremonial-symbolic, in which the preamble serves to consolidate national identity but lacks binding legal force; 2) the interpretive, in which the preamble is granted a guiding role in statutory and constitutional interpretation; and 3) the substantive, in which the preamble serves as an independent source for constitutional rights..$^{60}$

It appears that the legal functions of the Preamble of the 1945 Constitution vary from time to time. In 1945, the Preamble, which includes Pancasila in it, was viewed as a "forum a meeting point for all the different parties and groups, a common denominator of all ideologies and stream of though existing in Indonesia." ${ }^{\prime 61}$ Preamble become one of the most important documents to show the national identity. From the deliberation of the constitutional drafters, it appears that the preamble serves as a means to unify the people with different ethnicities, religions, political affiliation, and traditions. Pancasila was agreed by the founding fathers to be the state ideology and accepted by the people.
In 1959, particularly after the 1959 Presidential Decree, Pancasila became part of the authoritarian regime's justifying ideology. Rather than serve as a common platform for the different political ideologies in Indonesia, Pancasila served as an exclusive ideology standing in opposition to other ideologies and streams of thought. ${ }^{62}$ With the Soekarno Guided Democracy, Pancasila serves as the government political means to advance its political agenda. This situation stayed the same until the fall of Soekarno Old Order Government.

In the beginning of the New Order era, the government promised to implement the 1945 Constitution "purely and consistently." The New Order government learned from experience of the Old Order government which did not consistently apply the Constitution. This promise however far from real. The New Order government maintained the monopoly on the interpretation of Pancasila as through various means of indoctrination. ${ }^{63}$ the Constitutional Preamble operated as a tool to advance the government political interest. At the same time, however, the Preamble served as a tool to consolidate national identity and to maintain the unity of the country. The Preamble, however, was absent of binding legal force. ${ }^{64}$ There was no legal avenue to use the Preamble as a guiding principle in statutory or constitutional interpretation.

At the same time, In the New Order government, the Preamble of the 1945 Constitution enjoyed higher statutes compared to the body of the Constitution. In the beginning of the New Order period, the government supported by the national parliament and military reaffirmed Pancasila to be the foundation and the state philosophy. ${ }^{65}$ Pancasila as stated in the Preamble was the main source of national ethic, regulation and pubic policies. ${ }^{66}$ This

60 Liav Orgad, The Preamble in constitutional interpretation, Op.cit, p. 722.

61 Nasution, Adnan Buyung. The aspiration for constitutional government in Indonesia: a socio-legal study of the Indonesian Konstituante, 1956-1959. Pustaka Sinar Harapan, 1992. p. 30-35.

62 Bali, Asli U., and Hanna Lerner. "Constitutional Design Without Constitutional Moments: Lessons from Religiously Divided Societies." Op.cit p. 262.

Ibid.

64 Liav Orgad, The Preamble in constitutional interpretation, Op.cit., p. 722.

65 David Bourchier and Vedi R. Hadiz, Indonesia Politics and Society: A reader, Routledge New York 2003, p. 100-101.

66 Masykuri Abdillah, Actualization of Indonesian State Philosophy in the Context of Modern Democratic State Op.cit., p. 125. 
can be seen some constitutional law scholars ${ }^{67}$ and the government ${ }^{68}$ considered that the Preamble could not be amended because the Preamble contains the state ideology and the national identity. ${ }^{69}$ Even the body of the Constitution which constitutionally could be amended, ${ }^{70}$ the government add more requirements which make amending the constitution more difficult. The issuance of the MPR decree which determines Pancasila as source of all legal source (sumber dari segala sumber hukum) also support this assertion. ${ }^{71}$ During these two eras, the 1945 Constitutional Preamble may be best described as the ceremonial symbolic. It serves to consolidate national identity but lacks of legal force. At the same time, it is also fair to say that the Pancasila mentioned in the Preamble was used by the governments of the day to advance their political interests.

This function, however, changed significantly after the recent constitutional amendments in 19992002. Apart from its function as an expression of national identity, the Preamble serves as guiding role in statutory and constitutional interpretation. The recent constitutional amendments changed both the content and the structure of the Constitution. the Preamble of the 1945 Constitution, however, remains the same. People's Consultative Assembly (the MPR) --a state institution responsible to amend the Constitution-agreed that the Preamble of the 1945 Constitution would not be amended. ${ }^{72}$ This is because the Preamble of the Constitution contains the national goals which reflect the hope of the people who live in plural and diverse society. ${ }^{73}$ The Preamble also contains the national ideology that unifies the community (common platform).

The updated Constitution expressly stated that, "By the amendment to this Constitution, the Constitution of the Republic of Indonesia of the Year 1945 shall consist of the Preamble and the Articles." "Th This provision can be interpreted that Preamble and Articles are the two components of the Constitution. This provision, however, does not explicitly mention whether the preamble and articles have equal status.

In addition, the updated Constitution opens the possibility to amend the Constitution. Article 37 determines the procedures to change the Constitution. It says,

(1) A proposal for amendment to the articles of the Constitution can be set out in an agenda for a session of the People's Consultative Assembly if submitted by at least $1 / 3$ of the sum of the members of the People's Consultative Assembly.

(2) Every proposal to amend articles of the Constitution shall be submitted in writing and clearly indicate the part proposed for amendment and the reason therefor.

(3) In order to amend articles of the Constitution, a Session of the People's Consultative Assembly shall be attended by at least $2 / 3$ of the sum of the members of the People's Consultative

67 For example, Hamid Attamimi, Maria farida, and Notonagoro (Notonagoro coined the term: Pancasila as staatsfundamental norm) place Pancasila as state fundamental norm which have higher status than body of the constitution. Indrati, Maria Farida, and Maria Farida. "Ilmu Perundang-Undangan: Jenis, Fungsi dan Materi Muatan.” Yogyakarta: Kanisius (2007). Attamimi, A. Hamid S. "Peranan keputusan presiden Republik Indonesia dalam penyelenggaraan pemerintahan negara: suatu studi analisis mengenai keputusan presiden yang berfungsi pengaturan dalam kurun waktu Pelita I-Pelita IV.” (1990).

68 The New Order government promised to, "defend Pancasila and UUD 1945 and purely and consistently implement them." (mempertahankan Pancasia dan UUD 1945 dan melaksanakannya secara murni dan konsekuen). Muchson AR, Pancasila dan UUD 1945 Dalam Kehidupan Bangsa dan negara Republik Indonesia Universitas Negeri Yogyakarta 2009 p. 52.

69 Ibid. p 6.

Art 3 and Art 37 of the 1945 Constitution.

1 TAP MPRS No. XX/MPRS/1966 tentang Memorandum DPR-GR mengenai Sumber Tertib Hukum Republik Indonesia.

72 Majelis Permusyawaratan Rakyat Republik Indonesia, Panduan Pemasyaratan Undang-Undang Dasar Negara Republik Indonesia Tahun 1945: Sesuai dengan urutan Bab, Pasal, dan Ayat, Sekretariat Jenderal MPR RI 2007 hlm. 14-15. One of the five basic agreements of the MPR during the recent constitutional amendments. Foreword the Chief Justice of the Constitutional Court of the Republic of Indonesia The Constitutional Court of the Republic of Indonesia, The 1945 Constitution of the Republic of Indonesia and Law of The Republic of Indonesia Concerning the Constitutional Court, 2015 p iv.

73 Jimly Asshiddiqie, Ideologi, Pancasila, dan Konstitusi “Ideology, Pancasila and Constitution” p. 7.

74 Art. II Additional Provisions the 1945 Constitution (post 1999-2002 constitutional amendments). 
Assembly

(4) The resolution to amend article of the Constitution shall be conducted by the approval of at least fifty percent plus one member of the People's Consultative Assembly.

(5) Particularly regarding the form of the unitary State of the Republic of Indonesia no amendment can be made.

This article expressly mentions the process of amending the body of the 1945 Constitutionnot the preamble. It does not say anything whether the Preamble of the Constitution can be amended. It appears from the wording of Article 37, only the articles of the Constitution can be amended. Does it mean that the Preamble is unamendable? The short answer is unclear. If the Preamble cannot be changed, why Article 37 (5), which prohibit to alter Unitary State of Republic Indonesia, did not also include the Preamble? Article 37 (5) clearly mentions that the Unitary State of the Republic of Indonesia cannot be amended. If the Preamble cannot be amended, it should be included in this provision. Perhaps the MPR refused to include the Preamble of the Constitution in this article to avoid a speculation that the Preamble is equal to the articles of the Constitution.

Where did the People's Consultative Assembly (the MPR) state its intention not to amend the Preamble, then? Rather than expressly mentioned in the body of the Constitution, the MPR chose to mention its purpose in the five basic agreements which was formulated by the MPR prior to the constitutional amendments. These five-basic agreements include the agreement of the constitutional drafters (1) not to amend the Preamble of the Constitution; (2) to retain the Unitary State of the Republic of Indonesia; (3) to reaffirm the presidential government system; (4) to incorporate the Elucidation to the Constitution of 1945 containing normative matters into the articles; and (5) to conduct the amendment by means of addenda. ${ }^{75}$ Among the five basic agreement we can see the intention of the MPR to retain the unitary state which was then expressly stated in Article 37 (5) of the Constitution. The question is why the MPR did not apply similar method to the Preamble if the intention of the MPR is the same, i.e., not to amend the Preamble? This question so far remained unanswered.

Apart from the unanswered question mentioned above, it is safe to say that formally there is no constitutional provision that explicitly mention that the Preamble can be amended or cannot be amended (Article 37). The People's Consultative Assembly's intention not to amend the Preamble expressly stated in the five basic agreements of the constitutional amendments. This means whether or not the Preamble of the Constitution can be amended depends heavily on the agreement of the People's Consultative Assembly.

If we connect Article II Additional Provision (which stated that the Constitution consists of the Preamble and the Body/Articles) to Article $24 \mathrm{C}$ (which stipulate the power of the Constitutional Court to review the constitutionality of statutes against the Constitution), we may say that both the Preamble and the Articles can be used as tools to test the constitutionality of statutes. This is because the Preamble and articles are the two elements of the Constitution. Article II Additional Provision and Article $24 \mathrm{C}$ indicate that the Preamble and the articles of the Constitution enjoy an equal status in the sense that both can be used as a means to examine the validity of statutes. They are two important elements of the Constitution.

In addition, it is not uncommon that petitioners on judicial review cases as well as the Constitutional Court Justices cited the constitutional preamble as their constitutional basis in submitting the petitions or in delivering the court rulings. Such petitions and court rulings include petitions and court decisions on judicial review related to right

75 Foreword the Chief Justice of the Constitutional Court of the Republic of Indonesia, Op.cit., 2015 p iv. 
to education ${ }^{76}$, rights to work, ${ }^{77}$ rights to water $^{78}$ and other economic and social rights cases. In these cases, the preamble of the constitution that is often cited is the paragraph concerning national goals and the national ideology Pancasila. ${ }^{79}$ In many cases, the Constitutional Court refers to the Preamble of the Constitution as a way to find the substantive justice (keadilan substantive). That said the preamble which contains Pancasila acts as an instrument to ensure that all types of legislation in line with the Constitution and the state ideology. ${ }^{80}$

Based on the discussion mention above, it can be concluded that there is a shift regarding the status of the Preamble. In the past, particularly during Old Order and New Order era, the Preamble of the 1945 Constitution had higher status compared to the body of the constitution. This can be seen from the Elucidation of the Constitution and some government policies which support the supremacy of the constitutional Preamble. At the same time, however, the Preamble lacked of legal binding. The Preamble was also used by the governments of the day to advance their political interests.

This situation changed significantly after the fall of the New Order government. The Preamble and the articles are the two components of the 1945 Constitution (post 1999-2002 constitutional amendments). ${ }^{81}$ That said the status of the Preamble is equal to the Articles of the Constitution in the sense that they both the elements that establish the updated Constitution. This assertion is supported by Article II Additional Provision and Article $24 \mathrm{C}$ which stated that the Constitution (which consists of the Preamble and articles) can be used as a means to review the constitutionality of statutes.

In other words, after recent constitutional amendments, the functions of the Preamble changed substantially. It may serve as a guiding role in interpreting the statutes and the constitution. The change of the Preamble's functions is because the updated Constitution establishes a new judicial institution i.e. the Mahkamah Konstitusi (the Constitutional Court) which have the power to conduct constitutional review. The Constitutional Court is authorized to test the constitutionality of statutes. In doing so, the Court refers to the 1945 Constitution, which consist of the Preamble and the articles, as the constitutional reference to examine the validity of the laws. Therefore, theoretically, both the Preamble and the Articles of the 1945 Constitution can be used as tools to examine the validity of statutes. In Liav Orgad words, the 1945 Constitutional Preamble of the 1945 constitution (post the 1999-2002 constitutional amendments) acts as the interpretative function. ${ }^{82}$

\section{Conclusion}

This paper has answered the question regarding the functions of Preamble of the Indonesian Constitution i.e. the 1945 Constitution.

76 These include, inter alia, The Decision of the Constitutional Court No. 12/PUU-III/2005, The Decision of the Constitutional Court 026/PUUIII/2005, The Decision of the Constitutional Court 026/PUU-IV/ 2006 The Decision of the Constitutional Court 24/PUU-V/2007 The Decision of the Constitutional Court No. 13/PUU-VI/2008.

77 These include petition Number 96/PUU-XI/2013; petition number 69/PUU-XI/2013; petition 100/PUU-X/2012; petition 82/PUU-X/2012; petition 9/PUU-X/2012; petition 9/PUU-X/2012; petition 70/PUU-IX/2011; 58/PUU-IX/2011; petition 37/PUU-IX/2011; petition 27/PUUIX/2011; petition 19/PUU-IX/2011; petition 115/PUU-VII/2009; petition 012/PUU-1/2003. The petitions mentioned above essentially questioned the constitutionality of Law 13/40/2004 on Manpower and other relevant laws such as Law on Sistem Jaminan Sosial Nasional. The petitioners argue that some provisions of this law violated their constitutional rights and national goal i.e. the social welfare as stated in the preamble of the 1945 Constitution. In judicial review on cases related to economic and social rights, the petitioners often use the preamble of the constitution as a constitutional basis when they filed the case to the Court. The national goals that expressly mentioned in the preamble are "mencerdaskan kehidupan bangsa, memajukan kesejahteraan umum dan ikut melaksanakan ketertiban dunia yang berdasarkan kemerdekaan, perdamaian abadi dan keadilan sosial."

78 The Decision of the Constitutional Court 058-059-060-063/PUU-II/2004 and 008/PUU-III/2005.

79 National goals include educating the nations and advancing the social welfare (mencerdaskan kehidupan bangsa dan memajukan kesejahteraan umum). The Pancasila consists of 5 precepts which in short include (1) believe in Mighty God (2) humanity (3) unity of Indonesia (4) democracy (5) social welfare.

80 Tanto Lailam, “Analisis Praktik Pengujian Formil Undang-Undang Terhadap Undang-Undang Dasar 1945”, Pranata Hukum, Volume 6 Nomor 2 Juli 2011,p. 149

81 Article II Additional Provision of the 1945 Constitution (post-1999-2002 constitutional amendments).

82 Liav Orgad, The Preamble in constitutional interpretation, Op.cit. p. 722. 
It found that the roles of the Preamble of the 1945 Constitution are different from time to time. In the past, especially during Old Order era and New Order era, the Preamble enjoyed its supreme status. At the same time, however, the Preamble lacks legal binding force. There was no legal mechanism available to enforce the Preamble of the Constitution. The Preamble (which consist the Pancasila) also became a tool of the governments to advance their political interests.

This circumstance changed significantly in the post-New Order government. The recent constitutional amendments in 1999-2002 changed both the content and the structure of the Constitution. The updated Constitution expressly mention that the 1945 Constitution consists of Preamble and Articles. In addition, Article $24 \mathrm{C}$ stipulates that the Constitutional Court has the power to review the constitutionality of statutes against the Constitution.
These two provisions indicate that the Constitution which consists of the Preamble and Article have a legal function. They can be used to review the constitutionality of statutes. In other words, the Preamble has an interpretive function since the Constitution (which consist of the Preamble and articles) becomes the reference in determining the constitutionality of statutes. Whether or not a statute constitutional depends on whether or not it is consistent with the Constitution. In this case, the Preamble and the articles of the Constitution have a legal binding force. However, it does not mean that the Preamble does not have non-legal purpose. The 1945 Constitutional Preamble still reflects social, political identity and also expresses the common goals of the nation. Thus, it can be said that 1945 Constitutional Preamble serves a unique force both the legal and non-legal purposes.

\section{REFERENCES}

\section{A. Buku}

Abdillah, Masykuri, Actualization of Indonesian State Philosophy in the Context of Modern Democratic State in The Path to Alliance of Civilizations Through the Asian Community Alparslam Acikgenc, Choi Woo, Won, and Orhan Adiguzel (eds.).

Attamimi, A. Hamid S, 1990, Peranan keputusan presiden Republik Indonesia dalam penyelenggaraan pemerintahan negara: suatu studi analisis mengenai keputusan presiden yang berfungsi pengaturan dalam kurun waktu Pelita I-Pelita IV, disertasi, Program Doktor Fakultas Hukum Universitas Indonesia, Jakarta.

Bahar, Saafroedin, and Nanie Hudawatie, 1998, Risalah Sidang BPUPKI dan PPKI, Sekretariat Negara, Jakarta.

Bali, Asli U., and Hanna Lerner, 2016 Constitutional Design Without Constitutional Moments: Lessons from Religiously Divided Societies.

Burchier, David and Hadiz, Vedi R, 2003, Indonesian
Politics and Society: A Reader, Routledge.

Foreword the Chief Justice of the Constitutional Court of the Republic of Indonesia, 2015, The 1945 Constitution of the Republic of Indonesia and Law of The Republic of Indonesia Concerning the Constitutional Court, Secretariat general and Registrar of the MKRI, Jakarta.

Frosini, Justin Orlando, 2012, Constitutional Preambles. At a Crossroads Between Politics and Law, Maggioli Editore.

Indrati, Maria Farida, 2007, Ilmu PerundangUndangan: Jenis, Fungsi dan Materi Muatan. Kanisius, Yogyakarta.

MPB. Manus, et all, 1993, Tokoh-tokoh Badan Penyelidik Usaha-Usaha Persiapan Kemerdekaan Indonesia I \& II "Leading Figures of Committee for the Preparation of the Indonesian Independence", Departemen Pendidikan dan Kebudayaan, Jakarta.

Mackie, J.A.C., 1963, Indonesia Constitution 1945-60, in Richard Neville Spann, 
Constitutionalism in Asia at.178, Asia

Publishing House.

Muchson AR, 2009, Pancasila dan UUD 1945

Dalam Kehidupan Bangsa dan Negara

Republik Indonesia, Universitas Negeri

Yogyakarta.

Nasution, Adnan Buyung, 1992, The aspiration

for constitutional government in Indonesia:

a socio-legal study of the Indonesian

Konstituante, 1956-1959, Pustaka Sinar Harapan, Jakarta.

Vickers, Adrian, 2005, A History of Modern Indonesia, Cambridge University Press, New York.

\section{B. Journal Article}

Frosini, Justin O., Constitutional Preambles at a Crossroads Between Politics and Law (2012); Ebrahim Afsah, Book Review, 11 Int'l J. Cons. L. 831-34 (2013) reviewing Frosini.

Ginsburg, Tom Nick Foti, and Daniel Rockmore, "We the Peoples": The Global Origins of Constitutional Preambles, 46 Geo. Wash. Int'l L. Rev. 305.

Lailam, Tanto, "Analisis Praktik Pengujian Formil Undang-Undang Terhadap Undang-Undang Dasar 1945", Pranata Hukum, Vol. 6 No. 2 , Juli 2011.

Law, David S, Constitutional Archetypes, Texas, Law, Review, Vol. 95, 2016.

Orgad, Liav, "The Preamble in constitutional interpretation," I.CON, Vol. 8, No. 4, 2010.

Smith, Peter J., and Robert W. Tuttle, "God and State Preambles", Marq. L. Rev, Vol.100, 2016.

\section{Thesis Paper}

Ismail, Faisal, 1995, Islam, Politic and Ideology in Indonesia: A study of the Process of Muslim Acceptance of the Pancasila, Dissertation Mc Gill University Montreal.

\section{Paper}

Asshiddiqie, Jimly, Tanpa Tahun, "Ideologi, Pancasila, dan Konstitusi”, Makalah, Mahkmah Konstitusi.

\section{E. Constitutions and Legislation}

The 1945 Constitution

The 1949 Federal Constitution

The 1950 Provisional Constitution

The U.S. Constitution

The South Africa Constitution

The Spanish Constitution

Art. II Additional Provisions the 1945 Constitution (post amendment).

Art 3 and Art 37 of the 1945 Constitution.

Penjelasan UUD 1945 (the elucidation of the 1945 Constitution).

TAP MPRS No. XX/MPRS/1966 tentang Memorandum DPR-GR mengenai Sumber Tertib Hukum Republik Indonesia. 